\title{
THE IMPLEMENTATION OF MARKETING STRATEGY ON DISTRIBUTOR COMPANY (CASE STUDY AT PT HANNA INSTRUMENTS INDOTAMA)
}

\author{
Azhar Azzura Bachtiar ${ }^{1}$, Purwanto $^{2}$ \\ Management Study Program, Faculty of Business, President University \\ Email: Purwanto@president.ac.id \\ Received: September $15^{\text {th }} 2021$ \\ Approved: October 20 2021
}

\begin{abstract}
This research purposes to describe the implementation of $7 P$ 's marketing strategy at PT Hanna Instruments Indotama towards purchase decision. In this research using some indicators which one is like product, price, place, promotion, people, process, and physical evidence. To collecting the data there are 97 respondents who are using Hanna Instruments product through questionnaire at several industries located in Bandung. The research method applied a quantitative method with descriptive approach using Statistical Package for the Social Sciences (SPSS) analysis. The consequences of this research show that price, promotion and place has no influence to purchase decision. It can conclude 4 out of 7 hypotheses show a significant influence on purchase decision. The influence of product, people, process, physical evidence. The implementation of 7P's as marketing strategy toward purchase decision accounts for $61.9 \%$ and the other $38.1 \%$ is account for another factor that does not discussed.
\end{abstract}

Keywords: Product, Price, Place, Promotion, Marketing Strategy, Marketing Mix, Purchase Decision

\section{Intoduction}

Laboratory tools and equipment is unique and the most reliable tools (Olabanji, 2018). Usually, laboratory tools and equipment are needed for the medical labs, laborer. But, if we see to the detail material that used in laboratory itself, it might be used for industrial sector. There are several types include freezers, ovens, or an incubator, refractometers, calorimeters, etc. In Indonesia, the exercise of distribution also utilization of laboratory equipment has started since 1970 and grown uniquely of the $90^{\text {th }}$ century.

Nonetheless, there are critical developments on both organic market sides in Indonesia research center market lately. An occurrence is the main of laboratory industry in the water analysis lab industry in Indonesia, and a few insights have likewise showed that the 
utilization in regards to lab gear results of Indonesia had increment alongside development of industry in Indonesia which have around 2000 unit/industry/year in2015 (Kemenkes RI, 2017).

PT. Hanna Instruments Indotama is a company which started at 1996 as main agent in Indonesia. Now, the center of this company is in Jakarta. That product is a water analysis laboratory equipment company which sells $\mathrm{pH}$ meters, photometers, titrators and controllers has completed appropriate decisions on point of reference to turn out to be the current leading water analysis laboratory equipment in Indonesia chemical manufacturing. Theoretically, purchase decision-making in organizational and consumer contexts has been treated separately, although many authors have pointed out that the differences between the two are more relative than absolute Coviello (2001); Fern (1984); Wilson (2000); Elizabeth (2001) Nevertheless, research on organizational and consumer buying behavior has developed around somewhat different theoretical assumptions on the nature of decision-making processes, especially in terms of their rationality, individuality, and idiosyncrasy (Wilson, 2000). This article elaborates on three aspects of purchase decision-making: the actors involved "who make the decisions", the purchase-decision task "what kinds of decisions are made", and the nature of the decision-making process "how the decisions are made".

In that sense, the writer was enthused and provoked to lead an inquiry joining hypothetical substance and useful issues above. Simultaneously, PT. Hanna Instruments Indotama was taken as the ordinary effective case among research inside equipment for modern and logical use in Indonesia, therefore, this paper mainly focuses on the effect of these factors on the marketing mix of the laboratory industry. This study focuses on the implementation of marketing mix strategy of PT Hanna Instruments Indotama laboratory industry.

\section{Literature Review}

These days, marketing is talk about as singular of the critical element in the accomplishment of a business something beyond selling also publicizing, which people regularly assume of, marketing of today, should be understand within the fresh feeling of fulfilling consumer needs (Kotler \& Armstrong, 2018). There are lots of method with the purpose of marketing is definite. Here are some explanations of marketing expert are approved to be sufficient, also accepted by the majority of marketing expert:

Marketing is method next to companies generate value used for consumers also 
construct solid customer connection in arrange to take a value from consumers within return (Kotler \& Armstrong, 2018). American Marketing Association AMA in Thomas (2013) defined that marketing is the demonstration, set of institution, and also process intended for create, communicate, convey, also exchange hand-outs that contain value for consumers, customers, partners, and individual at large.

The Chartered Institute of Marketing in Blythe (2005) defined marketing as the managing procedure in charge for identify, anticipate, and pleasing consumer necessities beneficially. Marketing be able to understand as the progression so as to company determines their consumer's necessities (need also want), convince individual's necessities, and in conclusion obtain the turnover. Marketing has a tough correlation toward an association as it covers mainly of the external actions of the association. Thus, in sort to achieve accomplishment, organization must think about the marketing as a crucial part of the action.

Figure 2.

Independent Variable

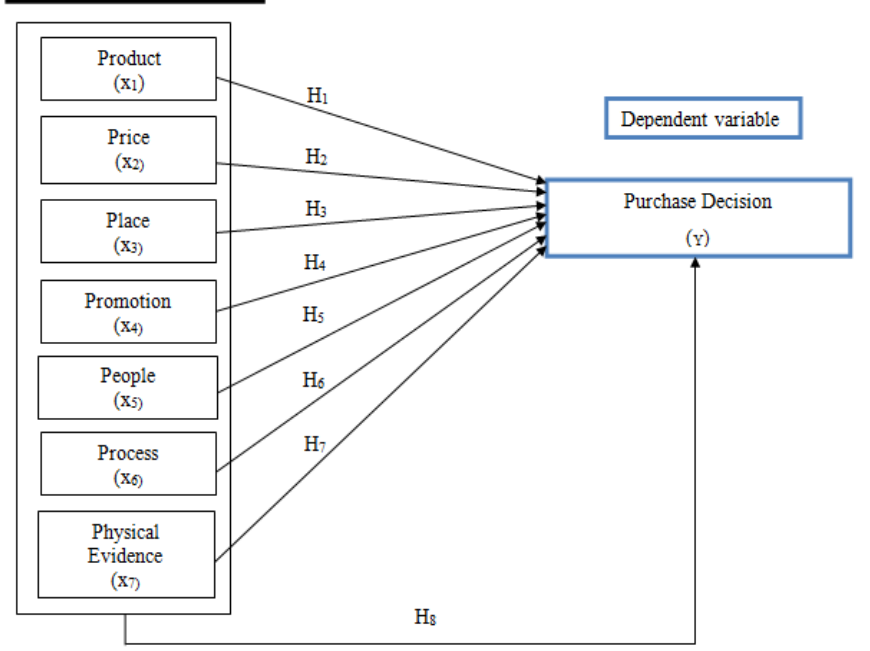

Theoretical Framework

Source: Adjusted by Researcher, 2020

Regarding the problem and theoretical framework above, hypothesis is determined, like follows:

$\boldsymbol{H}_{\boldsymbol{I}}$ : There is significant influence of product toward Hanna Instruments product.

$\boldsymbol{H}_{2:}$ There is significant influence of price toward Hanna Instruments product.

$\boldsymbol{H}_{3}$ : There is significant influence of place toward Hanna Instruments product.

$\boldsymbol{H}_{4}$ : There is significant influence of promotion toward Hanna Instruments product.

$\boldsymbol{H}_{5}$ : There is significant influence of people toward Hanna Instruments product.

$\boldsymbol{H}_{6}$ : There is significant influence of process toward Hanna Instruments product.

$\boldsymbol{H}_{7}$ : There is significant influence of physical evidence of PT Hanna Instruments Indotama product availability.

$\boldsymbol{H}_{8}$ : There are significant influences of product, price, place, promotion, people, process, physical evidence toward purchase decision at PT Hanna Instruments Indotama 


\section{Methodology}

Quantitative research can be utilized because of social inquiries of factors inside the research. "Quantitative researchers seek explanations and forecast that will create to different people and places. The goal is to build up, affirm, or approve connections and to develop generalizations that contribute to theory" (Leedy \& Ormrod, 2001). Quantitative research starts with a problem statement and involves the formation of a hypothesis, a literature review, and a quantitative data analysis. "Employ strategies of inquiry such as experimental and surveys, and collect data on predetermined instruments that yield statistical data" (Creswell, 2003). The findings from quantitative research can be predictive, explanatory, and confirming. The next section focuses on quantitative research methodology.

The primary target of this study is to inform the present position of PT Hanna Instruments Indotama in water analysis industry. Then, more important, PT Hanna Instruments Indotama success in the water analysis industries of Indonesia by applying the marketing mix 7Ps is purposely explained. Thus, there isn't just single point inside this postulation, and the two of them respect the clear and logical. Saunders et al. (2009) indicated that this kind of studies is classified "descripto explanatory studies", which reflect on generally suitable for this proposal by the creator.

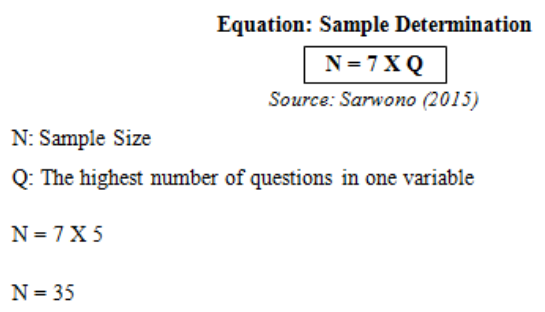

From the equation above it can be concluded that in this research, if the minimum respondent is 35 . The total sample is depending on the highest number of questions in one variable is maximum 5 questions. Collected from consumer of PT Hanna Instruments Indotama and based on the accidental sampling that used in this research, researcher collected 97 data from several employees on fabric around Bandung city.

According to Nazir (2013) Data collection is a methodical and consistent method to gain the essential information. According Sugiyono (2017) data collection techniques can be done with interviews, questionnaire, observation and combined all three. This research will be use 
Journal of Management and Leadership

Vol.4 No.1, May 2021

questionnaire as the research method to get the data source.

Table 1. Reliability test result

\begin{tabular}{|c|c|c|c|c|}
\hline No & Variable & $\begin{array}{c}\text { Cronbach } \\
\text { 's Alpha }\end{array}$ & $\begin{array}{c}\text { Number of } \\
\text { Question Items }\end{array}$ & Reliability \\
\hline 1 & Product $\left(\mathrm{X}_{1}\right)$ & 0.774 & 5 & Reliable \\
\hline 2 & Price $\left(\mathrm{X}_{2}\right)$ & 0.840 & 4 & Reliable \\
\hline 3 & Place $\left(\mathrm{X}_{3}\right)$ & 0.862 & 4 & Reliable \\
\hline 4 & Promotion $\left(\mathrm{X}_{4}\right)$ & 0.629 & 4 & Reliable \\
\hline 5 & People $\left(\mathrm{X}_{5}\right)$ & 0.901 & 5 & Reliable \\
\hline 6 & Process $\left(\mathrm{X}_{6}\right)$ & 0.916 & 5 & Reliable \\
\hline 7 & Physical Evidence $\left(\mathrm{X}_{7}\right)$ & 0.920 & 5 & Reliable \\
\hline 8 & Purchase Decision & 0.924 & & Reliable \\
\hline \multicolumn{4}{|c|}{ Total statement } & 32 \\
\hline
\end{tabular}

Sources: Primary Data, 2021

After distributing the questionnaire to 30 respondents, in the pre-test, the primary thing to complete is to play out a legitimacy test. Inside this case researcher choose Pearson Relationship utilizing SPSS 23.0 programming to help analyst in gathering the necessities of instruments authority.

Normality test is act upon to test whether in the relapse model, the dependent variable also the independent variable equally has a standard distribution or not. Normality test is gained based on the normal possibility plot chart. Also, the subsequent one if the information spreads a long way from the slanting and or doesn't follow the course of the inclining line or the histogram diagram doesn't show the normal appropriation design. At that point the relapse model doesn't gather the suspicion of normality (Susanto, 2013).

This multicollinearity test, are used to check whether the regression a model establishes a correlation among independent variables (independent). If there is connection amid independent variables, at that moment there is a multicollinearity problem inside the regression model. To notice the existence or nonappearance of multicollinearity in the regression model is by (Susanto, 2013).

Susanto (2013) explained that the coefficient of assurance is a worth showing the greatness of the progressions that happen because of different factors. In $r^{2}$ the coefficient of assurance is communicated. The coefficient of assurance $\left(\mathrm{r}^{2}\right)$ gauges how is capable the model's capacity to clarify the variety of the reliant variable.

Heteroscedasticity tests directed fully intent on testing whether or not in the regression model there is a fluctuation imbalance of the residue between one discernment to another. A 
decent regression model doesn't have heteroscedasticity, and a method of realizing it using a Scatter plot. On the points spread above and beneath the zeros and did not shape a guaranteed model then the regression model is free from heteroscedasticity problem (Susanto, 2013).

Within study of multiple regression utilize examination namely as hypothesis testing, this is device to choose sway worth of two self-sufficient variable or more to one ward variable. According to Susanto (2013) to exhibit the presence of helpful association or causal association of in any event two autonomous variables $\mathrm{X}_{1}, \mathrm{X}_{2}, \mathrm{X}_{3}, \mathrm{X}_{4}, \mathrm{X}_{5}, \mathrm{X}_{6}, \mathrm{X}_{7}$ against one variable next to $\mathrm{Y}$.

The formula as write below:

$$
Y=\beta_{0}+\beta_{1} X_{1}+\beta_{2} X_{2}+\beta_{3} X_{3}+\beta_{4} X_{4}+\beta_{5} X_{5}+\beta_{6} X_{6}+\beta_{7} X_{7 \varepsilon}
$$

where $Y=$ purchase decision, $\beta_{0}=$ constant $, \beta_{1}, \beta_{2}, \ldots, \beta_{7}=$ regression coefficient, $\mathrm{X}_{1}=$ Product, $\mathrm{X}_{2}=$ Price, $\mathrm{X}_{3}=$ Place, $\mathrm{X}_{4}=$ Promotion

, $\mathrm{X}_{5}=$ People, $\mathrm{X}_{6}=$ Process, $\mathrm{X}_{7}=$ Physical Evidence and $\varepsilon=$ error.

\section{Result}

\section{Pre - test Result}

Inside this pre- test result, it will examine the entirety of the result of pre-test, from the survey that has been spread out which determined and essentially comes. The discussion, which remembered for this section, there will be the pre - test results consist of the validity test and reliability test.

\section{Normality}

Normality test is a statistical test conducted to see how the distribution of data is. The method of normality test with SPSS can be done by using the Shapiro Wilk or Liliefors and Kolmogorov Smirnov test.

\begin{tabular}{|c|c|c|}
\hline \multicolumn{2}{|l|}{$\begin{array}{l}\text { One-Sample } \\
\text { Kolmogorov- } \\
\text { Smirnov Test }\end{array}$} & $\begin{array}{l}\text { Unstandardized } \\
\text { Residual }\end{array}$ \\
\hline \multirow{3}{*}{$\begin{array}{l}\mathrm{N} \\
\text { Normal } \\
\text { Parameters } s^{\mathrm{a}, \mathrm{b}}\end{array}$} & & 97 \\
\hline & Mean & .0000000 \\
\hline & Std. Deviation & 1.55369818 \\
\hline \multirow{3}{*}{$\begin{array}{l}\text { Most Extrem } \\
\text { Differences }\end{array}$} & Absolute & .140 \\
\hline & Positive & .140 \\
\hline & Negative & -.127 \\
\hline \multicolumn{2}{|c|}{ Kolmogorov-Smirnov Z } & 1.383 \\
\hline \multicolumn{2}{|c|}{ Asymp. Sig. (2-tailed) } & .044 \\
\hline
\end{tabular}

Figure 1. Normality Test 


\section{Multicollinearity}

Multicollinearity is a condition when there is a correlation among independent variables or between independent variables which are not mutually independent. The multicollinearity test is included in the classical assumption test. The multicollinearity test aiming to discover out which the regression model has correspondence among independent variables.

Table 2. Multicolinearity Test

Coefficients $^{\mathbf{a}}$
\begin{tabular}{|l|l|l|}
\multicolumn{1}{|c|}{ Model } & \multicolumn{2}{c|}{ Collinearity Statistics } \\
\cline { 2 - 3 } & Tolerance & VIF \\
\hline (Constant) & & \\
Product & .199 & 5.026 \\
Price & .157 & 6.387 \\
Place & .386 & 2.591 \\
Promotion & .946 & 1.057 \\
People & .221 & 4.517 \\
Process & .166 & 6.035 \\
Physical Evidence & .341 & 2.933 \\
\end{tabular}

a. Dependent Variable: PurchaseDecision

\section{Heteroscedasticity Test}

The heteroscedasticity test is used to identify the existence or absence of deviations since the classic assumption of heteroscedasticity, that is to say the inequality of variants of the residuals for all observations in the regression model. It can be seen in the following picture:

Figure 2. Heteroscedasticity Test

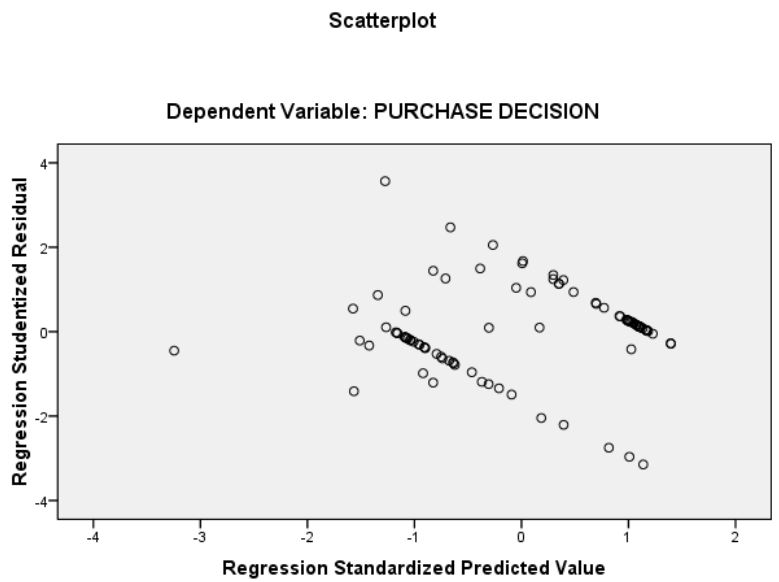




\section{Multiple Regression}

Table 3. Multiple Regression Test

\begin{tabular}{|c|c|c|c|c|c|}
\hline \multirow{2}{*}{ Model } & \multicolumn{7}{|c|}{ Coefficients $^{2}$} \\
& $\begin{array}{c}\text { Unstandardized } \\
\text { Coefficients }\end{array}$ & $\begin{array}{c}\text { Standardized } \\
\text { Coefficients }\end{array}$ & & \\
\cline { 2 - 5 } & $\mathrm{B}$ & Std. Error & Beta & $\mathrm{T}$ & \multirow{2}{*}{ Sig. } \\
\hline 1 (Constant) & 2.794 & 1.855 & & 1.506 & .136 \\
PRODUCT & .325 & .173 & .303 & 1.875 & .064 \\
PRICE & .222 & .218 & .176 & 1.017 & .312 \\
PLACE & -.173 & .118 & -.164 & -1.469 & .145 \\
PROMOTION & .034 & .034 & .069 & .991 & .324 \\
PEOPLE & .367 & .116 & .333 & 3.176 & .002 \\
PROCESS & -1.322 & .544 & -.364 & -2.429 & .017 \\
PHYSICAL & .399 & .125 & .481 & 3.196 & .002 \\
EVIDENCE & & & & & \\
\hline
\end{tabular}

a. Dependent Variable: PURCHASE DECISION $(Y)$

Source: Constructed using SPSS 23.0 (2021)

Based on table above, the equation of multiple linear regressions can be generated into:

\section{Purchase decision $=$ 2.794+0.367 People -1.322 Process + 0.399 Physical Evidence}

Referring to these results, the following interpretations can be made

\section{The implementation of product on purchasing decisions}

The result of hypothesis test 1 shows that product has no significant effect on purchase decision. The statistical analysis of SPSS version 23 supports this hypothesis. Based on t-test and f-test result, onside $\mathrm{T}$ test table the $\mathrm{t}$ value of product variable is 1.875 . The significant value was 0.064 greater than 0.05 . Therefore, $\mathrm{H}_{\mathrm{a} 1}$ is rejected, indicating which mean that product has no significant effect on purchase decision. Based on the statement above, implies to the improved feature of product with fascinating with great design, fascinating features of laboratory equipment and reward offers to customer will prompt the rising of customer buying decision (Djatmiko \& Pradana, 2015).

\section{The implementation of price on purchasing decisions}

The result of hypothesis test 2 shows that price has no significant effect on purchase decision. The statistical analysis of SPSS version 23 supports this hypothesis. Based on t-test and f-test result, onside $\mathrm{T}$ test table the $\mathrm{t}$ value of price variable is 1.017. The significant value was 0.312 greater than 0.05 . Therefore, $\mathrm{H}_{\mathrm{a} 1}$ is rejected, indicating which mean that price has no significant effect on purchase decision. Pricing for consumers who only want to spend money for a product which they need or liked (Kusmawati et al., 2018). 


\section{The implementation of place on purchasing decisions}

The result of hypothesis test 3 shows that place has no significant effect on purchase decision. The statistical analysis of SPSS version 23 supports this hypothesis. Based on ttest and f-test result, onside $\mathrm{T}$ test table the $\mathrm{t}$ value of place variable is -1.469 . The significant value was 0.145 greater than 0.05 . Therefore, $\mathrm{H}_{\mathrm{a} 1}$ is rejected, indicating which mean that place has no significant effect on purchase decision. The location of PT HII is close to the harbor then the result are in line with Rahmawanti et al. (2021) that variable price have significant relationship on purchase decision.

\section{The implementation of promotion on purchasing decisions}

The result of hypothesis test 4 shows that promotion has no significant effect on purchase decision. The statistical analysis of SPSS version 23 supports this hypothesis. Based on t-test and f-test result, onside $\mathrm{T}$ test table the $\mathrm{t}$ value of promotion variable is 991. The significant value was 0.324 greater than 0.05 . Therefore, $\mathrm{H}_{\mathrm{a} 1}$ is rejected, indicating which mean that promotion has no significant effect on purchase decision. So this is the reason of increasing promotion variable will assist to increasing on consumer buying decision and also more decreased promotion variable, it will assist to decreasing on consumer buying decision (Imaningsih, 2018).

\section{The implementation of people on purchasing decisions}

The result of hypothesis test 5 shows that people has significant effect on purchase decision. The statistical analysis of SPSS version 23 supports this hypothesis. Based on ttest and f-test result, onside $\mathrm{T}$ test table the $\mathrm{t}$ value of people variable is 3.176. The significant value was 0.02 lower than 0.05 . Therefore, $\mathrm{H}_{\mathrm{a} 1}$ is accepted, indicating which mean that people has significant effect on purchase decision When employees increase the friendliness, a tidier and more pleasing appearance regarding the provision of services to customers, this will positively influence the decisions of customers (Athar, 2021).

\section{The implementation of process on purchasing decisions}

The result of hypothesis test 6 shows that process has significant effect on purchase decision. The statistical analysis of SPSS version 23 supports this hypothesis. Based on ttest and f-test result, onside $\mathrm{T}$ test table the $\mathrm{t}$ value of process variable is -2.429 . The significant value was 0.17 lower than 0.05 . Therefore, $\mathrm{H}_{\mathrm{a} 1}$ is accepted, indicating which mean that process has significant effect on purchase decision. The research results show 
that although process can enhance the overall marketing mix of the company, it has little impact on the purchase decision of the company. (Christine, 2017).

\section{The implementation of physical evidence on purchasing decisions}

In accordance with the $\mathrm{T}$ test and $\mathrm{F}$ test result, the physical evidence variable is classified as variable that has significant effect on consumer buying decision. It shows on the $\mathrm{t}$ value in $\mathrm{T}$ test table value is 3.196 mean that each decrease of physical evidence variable will affect to increase in customer buying decision variable and significance value of physical evidence variable is .002 which lower than 0.05 , it means that the significance of physical evidence variable to the customer purchase decision activities. Based on Amirur (2017) even though physical evidence is one component to fulfill the marketing mix, it can be covered by the other elements with innovative product.

8. Simultaneous influence of product, price, place, promotion, people, process, physical evidence toward consumer purchase decision

The first way is to evaluate the value of $t$ table if the results of $f$ count $>t$ table, then there is a cause of the independent variable on the dependent variable. Calculating the value of the fable can be done with the following conditions, the significant level is 0.05 , while the degree of freedom of the test is $(K: n-k)=(7: 90)$ and the results obtained for the table are 3.27. Based on the results obtained, the value of $f$ count is $23,290>2.11$, as a result that $\mathrm{H}_{0}$ is rejected and $\mathrm{H}_{1}$ is accepted. It indicates that here is the influence of variable product, price, place, promotion, people, process, physical evidence on purchase decision. Therefore, the null hypothesis $\left(\mathrm{H}_{08}\right)$ is rejected and the alternative hypothesis $\left(\mathrm{H}_{\mathrm{a} 8}\right)$ is accepted.

\section{Coefficient Determination $\left(\mathbf{R}^{2}\right)$}

Table 4. $R^{2}$ result

Table 4.13 Coefficient Determination $\left(R^{2}\right)$

Model Summary

\begin{tabular}{|c|c|c|c|c|}
\hline Model & $\mathrm{R}$ & $\mathrm{R}$ Square & $\begin{array}{c}\text { Adjusted R } \\
\text { Square }\end{array}$ & $\begin{array}{c}\text { Std. Error of the } \\
\text { Estimate }\end{array}$ \\
\hline 1 & $.804^{\mathrm{*}}$ & .647 & .619 & 1.614 \\
\hline
\end{tabular}

a. Predictors: (Constant), PHYSICAL EVIDENCE, PROMOTION,

PRODUCT, PEOPLE, PLACE, PROCESS, PRICE.

Data Source: SPSS 23.0 results 
Based on the table of output results regarding the summary model above, it can be seen that the $r$ value is $0.804^{\mathrm{a}}$, the $\mathrm{r}$ square value is 0.647 , and the adjusted $\mathrm{r}$ square value is 0.619 and the standard estimated error value 1,614. In this study, the independent variables used were 7 variables. So, the value of the coefficient of determination can be seen from the adjusted $r$ square, which is 0.619 .

In this case, it can be concluded that the independent variable is $61.9 \%$ which comes from the calculation of adjusted $\mathrm{r}$ square $\mathrm{x} 100 \%$. While the remaining $38.1 \%$ obtained from $100 \%-61.9 \%$ is influenced by other things outside of this discussion.

\section{Conclusions and Recommendation}

In accordance to CHAPTER IV regarding the analysis of marketing mix of $7 \mathrm{ps}$ implementation the PT Hanna Instruments Indotama customer buying decision among industrial at Bandung West Java. Based on the research results in chapter IV, the researchers draw the following conclusions based on the scope and limitations:

1. Based on the result, product has no significant effect on purchase decision. But it does not mean that product of the company is not good, but there are product indicators discussed in this research that didn't meet customer expectations. The customers already know the product with a great feature good design and fascinating product. There is another factor or variable that significant influence on purchase decisions which not observe in this research and still needs to improve.

2. Based on findings, price has no significant effect by purchase decision. It means price is not a factor that influences purchase decision. The lower price with same feature at the market make the Hanna's product superior to other products.

3. Place has no significant effect on purchase decision of. It means place is not a factor that influence purchase decision. While the products come from main company, the sole agent in Indonesia is near with harbor for better distribution. On the other way, the customers no need to come to the office, because the employee will come directly to customer.

4. According to findings, promotion has no significant effect on purchase decision. Even though the promotion doesn't give significant influence to the purchase decision, the company should aware to improve promote their product in many ways. That is, the company will be known very well by the new customer that given by friends or colleague recommendation. 
5. People have a significant effect on purchase decision of. That is to say, the customer is satisfied with the employee of the company because they providing to come directly to the customer, and give the explanation to customer itself about guiding use of the product.

6. Based on a result, process has a significant effect on purchase decision. That is to say, flow of delivering the product to customer by employee itself is easy, both before purchasing and after sales. It makes the customer satisfied and creates willing to buy in return to buy the product.

7. Physical evidence has a significant effect on purchase decision. It means physical evidence is not a factor for purchase decision. The lower satisfaction customer of physical appealing will affect to physical evidence itself, but in other way, customer definitely purchase again to buy and give the recommendation after purchasing the product, they will know what the features that given by company trough employees.

According to the result, product, price, place, promotion, people, process and physical evidence have significant influence on purchase decision. While some variable give significant influence and some did not give significant influence, that is to say the marketing mix is an indicator of marketing performance to provide the effective marketing program.

\section{References}

Coviello. (2001). Contemporary Marketing Practice of Consumer and Business-to-business Firms: How Different Are They? Journal of Business \& Industrial Marketing, 382400.

Elizabeth. (2001). Executive and Consumer Decision Processes: Increasing Useful Sensemaking by Identifying Similarities and Departures. Journal of Business \& Industrial Marketing, 401-14.

Fern. (1984). The Industrial/consumer Marketing Dichotomy: A Case of Insufficient Justification. Journal of Marketing, 68-77.

Kemenkes RI. (2017). Rencana Aksi Kegiatan Tahun 2015-2019.

Kotler, P. T., \& Armstrong, G. (2018). Principles of Marketing (17 ed.).

Leedy, P., \& Ormrod, J. (2001). Practical Research: Planning and Design (7 ed.). Merrill Prentice Hall and SAGE Publications.

M. Saunders, P. L., \& Thornhill, A. (2009). Research Methods for Business Students. New York: Pearson.

Nazir, M. (2013). Metode Penelitian. Bogor: Ghalia Indonesia.

Olabanji, I. (2018, August 17). What is the Laboratory Tools and Equipment? Retrieved from healthsoothe.com.

Sugiyono. (2017). Metode Penelitian Kuantitatif, Kualitatif. Bandung: Alfabeta, CV. 
Journal of Management and Leadership

Vol.4 No.1, May 2021

Susanto, A. (2013). Sistem Informasi Akuntansi, Struktur-Pengendalian-Resiko-

Pengembangan. Bandung: Lingga Jaya.

Thomas, J. (2013). Marketing Concept: Examining AMA Definitions, Evolution, Influences.

Seventeenth AIMS International Conference on Management.

Wilson. (2000). Organizational Marketing. 780-96.

www.eiilmuniversity.ac.id. (n.d.). Consumer Behavior. 